\title{
EVALUATING UNDERGRADUATE ACCOUNTING PROGRAMS IN TURKEY ACCORDING TO INTERNATIONAL ACCOUNTING EDUCATION STANDARD (IES) 2
}

\author{
Filiz ANGAY KUTLUK
}

Ph.D., Assoc. Prof., Akdeniz University, Faculty of Applied Sciences, Department of Banking and Finance, angay@akdeniz.edu.tr

\author{
Adnan DÖNMEZ \\ Ph.D., Akdeniz University, Faculty of Economics and Administrative Sciences, \\ Department of Business Administration, adonmez@akdeniz.edu.tr

\section{Seçkin GÖNEN} \\ Ph.D., Dokuz Eylül University, Faculty of Economics and Administrative \\ Sciences, Department of Business Administration, seckin.gonen@deu.edu.tr
}

\begin{abstract}
Producing reliable and correct financial knowledge requires a strong accounting system in businesses and well educated accountants provided with necessary technical knowledge and skills, values and ethics. The International Accounting Education Standards Board (IAESB) which is a part of International Federation of Accountants (IFAC) establishes standards in professional accounting education area and issued eight International Education Standards. The aim of this study is to evaluate accounting education in the undergraduate accounting programs according to International Education Standard 2. After a brief information about International Education Standards, the undergraduate accounting programs' curriculums in Turkey are examined according to IES 2 Initial Professional Development - Technical Competence which prescribes the requirements of accounting education programs. The 2017 Edition Handbook of International Education Pronouncements includes the framework 2015 of the IESs. The curriculums are analysed according to the basic courses that are related to the 11 competence areas prescribed in IES 2. The credit-hour basis and compulsory/elective basis of the courses are also analysed. Results show that the basic courses of some competence areas such as 'Financial Accounting and Reporting' and some others are included in all of the programs' curriculums; some
\end{abstract}


Prestige International Journal of Management \& IT-Sanchayan, Vol. 8 (2), 2019, pp. 1-14 ISSN : 2277-1689 (Print), 2278 - 8441 (Online)

competence areas are included in almost all of the curriculums and the inclusion of some of them are inadequate.

Keywords: Accounting Education, Accounting Curriculum, International Accounting Education Standards

\section{INTRODUCTION}

Producing reliable and correct financial knowledge requires a strong accounting system in businesses and well educated accountants provided with necessary technical knowledge and skills, values and ethics. This can be achieved by a well organized accounting education. Accounting world has been developed rapidly and the significance of accounting education has been increased. Especially after the world famous accounting scandals, training qualified accountants became the core issue.

International Federation of Accountants (IFAC) is the global organization for the accountancy profession and contributes to the development of high quality standards and guidance and aims that accountancy profession be recognized as an esteemed leader in the development of strong organizations and economies (http://www.ifac.org).

The International Accounting Education Standards Board (IAESB), that is a part of IFAC, establishes standards in professional accounting education area that "prescribe technical competence and professional skills, values, ethics, and attitudes" and "increases the competence of the global accountancy profession-contributing to strengthened public trust" (https:/ /www.iaesb.org/ about-iaesb). The eight International Education Standards (IES) are as follows:

IES1- Entry Requirements to Professional Accounting Education Programs (2014)

IES 2-Initial Professional Development - Technical Competence (2015)

IES3-Initial Professional Development - Professional Skills (2015)

IES4-Initial Professional Development - Professional Values Ethics, and Attitudes (2015)

IES5-Initial Professional Development - Practical Experience (2015)

IES 6- Initial Professional Development - Assessment of Professional Competence (2015)

IES 7- Continuing Professional Development (2014)

IES 8- Professional Competence for Engagement Partners Responsible for Audits of Financial Statements (2016) 
Evaluating Undergraduate Accounting Programs in Turkey According To International Accounting Education Standard (IES) 2

Underlying concepts and definitions of IESs are presented by handbooks; the Handbook 2017 of International Education Pronouncements includes the Framework 2015 for IESs, the changes from the 2015 edition and proposed revisions to IESs 2,3,4 and 8 (Handbook,2017, 1; Exposure Draft 2018, 7). Besides that, in 2017 International Education Pronouncements Handbook that replaced 2015 volume, and determines International Education Standards' Framework; clear terminology changes are made, troubles that exist in drafts of standards are ruled out and typographic editing is performed (Handbook, 2017,1). On the basis of these advancements, coherence between standards is increased, clarity and accuracy of standards is upgraded. Through these information gathered, rearrangement of course curricula by educators would be an important step for upgrading education quality.

The scopes of the standards can be explained briefly as follows (Handbook of International Education Pronouncements, 2017):

IES1 is about entry level requirements to enter education programs of professional accounting that must be achieved by the end of Initial Professional development (IPD) by aspiring Professional accountants (p. 26).

IES 2 is about learning outcomes for technical competence (p.33);

IES 3 is about learning outcomes for professional skills such as intellectual, interpersonal and communication, personal and organizational skills (p.44);

IES 4 is about the learning outcomes for professional values, ethics that are necessary for a members of accounting profession (p.54);

IES 5 is about the practical experience required that candidate professional accountants need to demonstrate by the end of IPD (p. 69).

IES 6 is about the necessities to evaluate the professional competence of candidate accountants that they have to achieve until the end of IPD (p.79).

IES 7 is about the continuing professional development which is necessary for the professional accountants for retaining and improving professional competence needed to ensure good quality services which provide public trust in the profession (p.88).

IES 8 is about the professional competence that professional accountants that is necessary for audits of financial statements (p. 99).

IAESB concluded that the extant IESs need to be enhanced because a development is needed in areas of Information and Communications Technology (ICT) and 
Prestige International Journal of Management \& IT-Sanchayan, Vol. 8 (2), 2019, pp. 1-14 ISSN : 2277-1689 (Print), 2278 - 8441 (Online)

professional skepticism (Exposure Draft, 2018, 7). Professional accountants need these skills to perform their roles completely and provide high quality financial reporting and auditing. As the demand for these skills grows, IAESB proposed revisions to learning outcomes of IESs 2,3,4 and 8 for ICT and professional skepticism are expected "to improve the consistency, quality, and relevance of IPD and CPD (Continuing Professional Development) undertaken by aspiring and professional accountants" and to be effective for implementation approximately January 2021.

This study aims to examine accounting education of undergraduate accounting programs in Turkey with respect to International Education Standard 2 (IES 2) which is related to learning outcomes for technical competence.

\section{LITERATURE REVIEW}

Zaif and Ayanoglu (2007) examined the adequacy of accounting education by analyzing the accounting lessons in the curriculum of Business Administration Programs in Turkish universities. According to the results, most of the accounting lessons that are necessary for the technical knowledge and skill of the accountancy profession are contained in the curriculum but their proportion of the whole program lessons is only $14 \%$ and it wouldn't be enough to meet the necessities of the Accounting Education standards. The authors suggested that there should be also more Accounting-Finance undergraduate programs besides Business Administration Programs.

Uyar (2008) considered accounting education with respect to IESs in Economics, Business Management, Public Finance, Public Administration, International Relations and Law programs of Akdeniz University. According to the results there were adequate lessons about Accounting, Finance and Organizational and Business knowledge in Economics, Business Management and Public Finance programs with respect to IES but the lessons are inadequate in Public Administration, International Relations and Law programs. The lessons of Information technology knowledge were inadequate in all programs.

Subaşı and Demir (2009) examined the curriculums of Business Administration programs concerning accounting lessons. Results showed that there were accounting lessons with 170 different names. There were differences between state and foundation universities in terms of credit hours of the accounting lessons and being compulsory.

Çubukçu (2012) examined curriculum of the undergraduate and graduate Business Administration programs in Turkish universities with respect to International Education Standard 4 (IES 4) -Professional Values, Ethics and Attitudes and IEPS 1 Approaches to Developing and Maintaining Professional Values, Ethics, and 
Evaluating Undergraduate Accounting Programs in Turkey According To International Accounting Education Standard (IES) 2

Attitudes. Results showed that ethics courses were inadequate in undergraduate and graduate programs.

Pan and Perera (2012) examined whether Australian universities produce accounting graduates knowledge and skills and competencies required by the market. They surveyed employers of accounting graduates in a major metropolitan area in Australia to identify market expectations. The results showed that the proportions of the accountancy, business and liberal components and the coverage on most accountancy sub-disciplines at undergraduate accounting program were largely as the expectation of the market, but the expectation of the market that the understanding of graduates how accounting serves for businesses is high. The results also showed that accounting program had a heavy emphasis on accounting technical knowledge, but poor generic skills which enable the accounting graduates to apply the knowledge they gained through education to practice successfully.

Can and Demirci (2016) examined course curricula of Business, Political Science and Law Faculties in a university under IES 2 scope, and analyzed qualifications of educations between departments for acquiring profession certificate. Looking at research results, course curricula are not found sufficient for performing professional accounting and necessary educations are proposed to be added into curricula for becoming a field professional as the level stated in standards; Business Management Faculty has the most proper education curriculum for the standarts.

Gokten and Gokten (2016) examined the validity of IESs in Turkey and found that five of the eight standards are completely valid, IES 2 and IES 6 are partially valid and IES 3 is not valid in Turkey. They state that IES 2 is partially valid if the necessary importance will not be given to Information Technologies (p.61).

Öztürk and Erdoğan (2017) analyzed the content, diversity and ECTS's (European Credit Transfer System) of the accounting courses that are included in curriculum of Western Mediterranean Universities of Turkey and found that there are many accounting courses in curriculums of Faculties of Economics and Administrative Sciences of State Universities in this area. They suggest to increase the number of elective courses.

Tosunoglu, et al. (2018) inquired knowledge, ability and attitude aspects of accounting education via conducting survey amongst field professionals and academicians in Trabzon province in the context of international accounting education standards. As a result of findings gathered, there are significant differences of opinion between accounting field professionals and academicians.

Nasution, et al. (2018) highlighted the necessity of rapid integration of course curricula convenient with International Education Standards for qualification of 
Prestige International Journal of Management \& IT-Sanchayan, Vol. 8 (2), 2019, pp. 1-14 ISSN : 2277-1689 (Print), 2278 - 8441 (Online)

accounting profession, they found harmonization of IFRS and regulating legislation compatible with standards solely not enough for global competition.

Suttipun, et al. (2018) examined IFRS perceptions of field professionals within the context of International Education Standards by survey study made on 425 field professionals working in Thailand. According to results, professional qualifications of field professionals are appropriate with standards but have certain insufficiencies in analysis ability and ethical issues.

\section{METHOD}

This study considers accounting education of undergraduate accounting programs in Turkey with respect to International Education Standard 2 (IES 2-Initial Professional Development - Technical Competence) which is related to learning outcomes for technical competence. Professional competence is "the ability to perform a role to a defined standard" which integrates technical competence, professional skills and professional values, ethics, and attitudes (Handbook, 2017, p.38). Competence area is described as "a category for which a set of related learning outcomes can be specified". Learning outcomes "establish the content and the depth of knowledge, understanding, and application required for each specified competence area".

Main coverage is mentioned for each competence area in Handbook $(2017,34-37)$, but also in explanatory material, A9 (Handbook, 2017, 39), it is mentioned that the competence area "may not be identical to the names of prescribed courses or subjects or, the learning outcomes associated with one competence area may be achieved across more than one course or subject dedicated to that area.

The 11 Competence areas listed in Learning Outcomes for Technical Competence are as follows (Handbook, 2017, 34-37):

- Financial accounting and reporting

- Management accounting

- Finance and financial management

- Taxation

- Audit and assurance

- Governance, risk management and internal control

- Business laws and regulations

- Information technology

- Business and organizational environment

- Economics

- Business strategy and management 
Generally, Business Administration Programs have Undergraduate-level accounting courses in universities of Turkey where also future accountants are trained. There are also undergraduate programs that have education solely about accounting (and accounting and finance). This study contains accounting undergraduate programs of State, Private and Foundation Universities in Turkey which were chosen from the "Student Selection and Placement System Guide for Undergraduate Programs-2018" and had "accounting" name. Only the universities located in Turkey are included in the study. There are 15 programs:

$\begin{array}{ll}\text { Accounting } & 3 \\ \text { Accounting Information Systems } & 1 \\ \text { Accounting and Auditing } & 3 \\ \text { Accounting and Financial Management } & 8\end{array}$

Curriculums of all the undergraduate programs that are solely about accounting are examined especially in respect to IES 2 Initial Professional Development - Technical Competence which is related to the of accounting education programs' content and is effective from July 2015.

So, curriculums of the 15 programs are analyzed according to the 11 Competence Areas listed in IES 2 and according to the credit-hour basis. It is also mentioned whether the course is compulsory or elective. Each competence area is listed in a separate table with the courses mainly related to that area.

\section{FINDINGS}

11 competence areas are listed in 11 tables separately. The main courses related to the competence areas are listed according to the credit hour and whether they are compulsory or elective. The number of the programs that contain the course is written under the related credit hour/compulsory/elective column. For example if it is written " 3 " under " 4 C column", that means curriculum of 3 programs include that course as 4 credit hours and compulsory. Some of the courses that have different names but the same content are combined such as General Accounting and Financial Accounting.

Table 1. Courses of Financial Accounting and Reporting Competence Area

\begin{tabular}{|c|c|c|c|c|c|c|c|}
\hline Courses & $4 \mathrm{C}$ & $3 \mathrm{C}$ & $2 \mathrm{C}$ & $4 \mathrm{E}$ & $3 \mathrm{E}$ & $2 \mathrm{E}$ & \\
\hline Financial (General) Accounting* & 6 & 9 & & & & & \\
\hline Financial Reporting Standards** & & 1 & & & & & \\
\hline Financial Statements Analysis & & 1 & & & & & \\
\hline Corporate Accounting & 1 & 11 & & & 3 & & \\
\hline \multicolumn{8}{|l|}{ Accounting Information Systems } \\
\hline Year end Accounting Transactions & & 1 & & & & & \\
\hline Accounting Profession Regulations / Busine & ss Ethi & & 3 & 3 & 1 & 7 & 1 \\
\hline \multicolumn{8}{|c|}{ * 11 programs have also Financial (General) Accounting II } \\
\hline ** 6 programs have also Financial Reporting Standards II & & & & & & & \\
\hline
\end{tabular}


Prestige International Journal of Management \& IT-Sanchayan, Vol. 8 (2), 2019, pp. 1-14 ISSN : 2277-1689 (Print), 2278 - 8441 (Online)

Table 1 shows that Financial Accounting and Financial Reporting Standards courses are compulsory in all of the programs' curriculums; and Financial Statements Analysis course is also compulsory. There are also some other courses with different names, but cover almost the similar content of these courses. All of the programs' curriculums include these very important courses of 'Financial Accounting and Reporting' Competence Area. As it is seen, the courses included in Table 1 are mostly contained in the programs. Business Ethics course is included in all of the programs, but it is mostly elective. There are also many other courses which may be included in this area such as Banking Accounting, Expertise Accounting, Accounting Practices, Advanced Accounting and Foreign Trade Accounting (in more than half of the programs) and others.

Table 2. Courses of Management Accounting Competence Area

\begin{tabular}{|c|c|c|c|c|c|c|}
\hline Courses & $4 \mathrm{C}$ & $3 C$ & $2 \mathrm{C}$ & $4 \mathrm{E}$ & $3 E$ & $2 E$ \\
\hline Cost Accounting * & 1 & 14 & & & & \\
\hline Management Accounting & 1 & & & & 1 & \\
\hline Business Budgeting & & 1 & & & & \\
\hline
\end{tabular}

As it is seen in Table 2, Cost Accounting course is compulsory in all of the programs' curriculums and Management Accounting course is included in almost all of the programs' curriculums, mostly in compulsory basis. There are also many other courses in this area such as Strategic Cost Management.

Table 3. Courses of Finance and Financial Management Competence Area

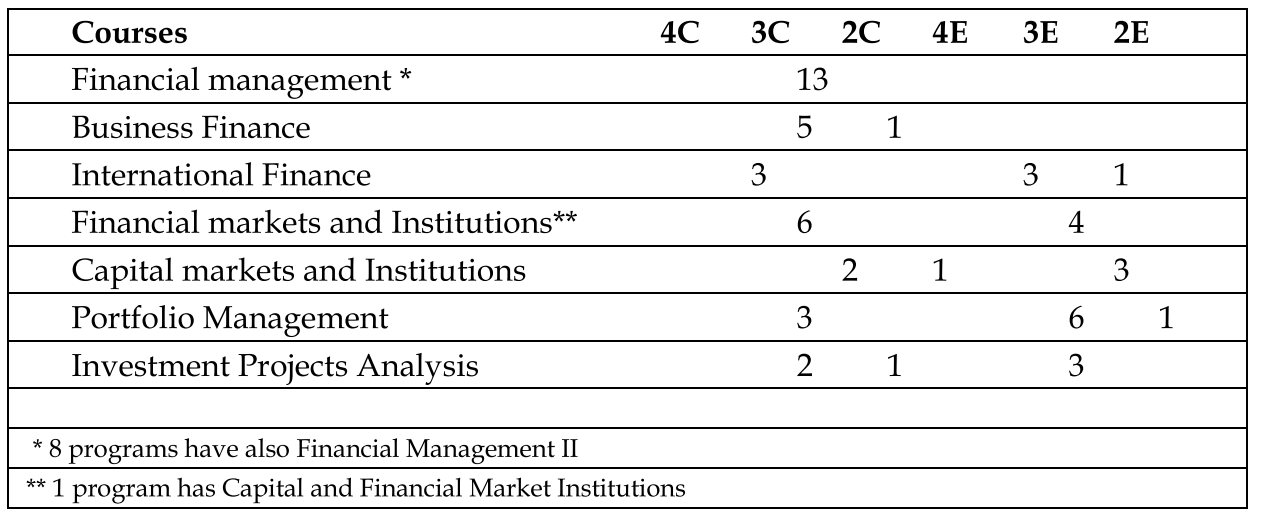

Table 3 shows that Financial Management course is included in almost all of the programs' curriculums and it is compulsory. Financial markets and Institutions and Portfolio Management courses are also included in most of the programs' curriculums. There are also many other courses in this area such as Credit Management, Derivatives, Financial Technics and others. 
Evaluating Undergraduate Accounting Programs in Turkey According To International Accounting Education Standard (IES) 2

Table 4. Courses of Taxation Competence Area

\begin{tabular}{|c|c|c|c|c|c|c|}
\hline Courses & $4 C$ & $3 C$ & $2 \mathrm{C}$ & $4 \mathrm{E}$ & $3 E$ & $2 E$ \\
\hline Tax law & & 9 & & & 4 & 1 \\
\hline Turkish Taxation & & 8 & 1 & & 4 & 1 \\
\hline
\end{tabular}

As it is seen in Table 4, Tax Law and Turkish Taxation course are mostly compulsory and included in almost all of the programs' curriculums. There are also courses such as Turkish Taxation Applications, Tax Accounting and Tax Auditing.

Table 5. Courses of Audit and Assurance Competence Area

\begin{tabular}{|c|c|c|c|c|c|c|}
\hline Courses & $4 C$ & $3 C$ & $2 \mathrm{C}$ & $4 \mathrm{E}$ & $3 E$ & $2 E$ \\
\hline Auditing & & 15 & & & & \\
\hline Auditing Standards & & & & & & \\
\hline
\end{tabular}

Table 5 shows that Auditing course is included in all of the programs' curriculum and totally compulsory.

Table 6. Courses of 'Governance, Risk Management and Internal Control' Competence Area

\begin{tabular}{|c|c|c|c|c|c|c|}
\hline Courses & $4 \mathrm{C}$ & $3 C$ & $2 \mathrm{C}$ & $4 \mathrm{E}$ & $3 \mathrm{E}$ & $2 \mathrm{E}$ \\
\hline Corporate governance & & & & & 5 & \\
\hline Risk management and/ Internal control & & & 1 & 1 & & 8 \\
\hline
\end{tabular}

As it is seen in Table 6, the inclusion of the basic courses of Governance, Risk and Internal Control competence area in the curriculums is inadequate.

Table 7. Courses of 'Business Laws and Regulations' Competence Area

\begin{tabular}{|c|c|c|c|c|c|}
\hline Courses & $3 C$ & $2 \mathrm{C}$ & $4 \mathrm{E}$ & $3 E$ & $2 \mathrm{E}$ \\
\hline Obligations Law & 11 & 3 & & & \\
\hline Labor Law/ Labor and Social Security Law & 5 & & & 4 & 1 \\
\hline Commercial Law * & 13 & 2 & & & \\
\hline Fundamental concepts of law & 10 & 4 & & & \\
\hline
\end{tabular}

Table 7 shows that Commercial Law course is in all of the programs' curriculums and in compulsory basis; Obligations Law and Fundamental Concepts of Law courses are in almost all of the programs' curriculums and in compulsory basis. Labor Law/Labor and Social Security Law courses are also more than half of the curriculums. There are also courses such as Corporate Law, Law of Commercial Papers, Executions and others. 
Prestige International Journal of Management \& IT-Sanchayan, Vol. 8 (2), 2019, pp. 1-14 ISSN : 2277-1689 (Print), 2278 - 8441 (Online)

Table 8. Courses of 'Information Technology' Competence Area

\begin{tabular}{|c|c|c|c|c|c|c|}
\hline Courses & $4 \mathrm{C}$ & $3 C$ & $2 \mathrm{C}$ & $4 \mathrm{E}$ & $3 \mathrm{E}$ & $2 \mathrm{E}$ \\
\hline Basic Information Technology * & & & 3 & & & \\
\hline Computer Aided Accounting ** & 2 & 8 & 1 & & 2 & \\
\hline Management Information Systems & & & & & & \\
\hline \multicolumn{7}{|c|}{ * 4 programs have also Basic Information Technology II } \\
\hline ** 9 programs have also Computer Aided A & & & & & & \\
\hline
\end{tabular}

As it is seen in Table 8, Basic Information Technology course is mostly included in the curriculums in compulsory basis. There are also courses about Office Software or advanced computer applications in Accounting. Accounting Information Systems and Accounting Systems and Organizations courses also include information technologies subjects and included in curriculums of some of the programs.

Table 9. Courses of 'Business and Organizational Environment' Competence Area

\begin{tabular}{|lrrrrrr|}
\hline Courses & 4C & 3C & 2C & 4E & 3E & 2E \\
\hline Business & & 14 & & & & \\
\hline Entrepreneurship & 1 & 3 & 1 & & 7 & 1 \\
\hline Marketing Management & & 2 & & & 2 & 1 \\
\hline Marketing Principles & & 3 & 1 & 1 & 1 & \\
\hline E-Commerce & & & 1 & 5 & 1 \\
\hline
\end{tabular}

Table 9 shows that Business course is included almost all of the curriculums in compulsory basis. Entrepreneurship course is mostly included in the curriculums in elective basis. There are also courses such as Business Management, Contemporary Management Technics and others.

Table 10. Courses of 'Economics' Competence Area

\begin{tabular}{|c|c|c|c|c|c|c|}
\hline Courses & $4 \mathrm{C}$ & $3 C$ & $2 \mathrm{C}$ & $4 \mathrm{E}$ & $3 \mathrm{E}$ & $2 \mathrm{E}$ \\
\hline Introduction to Economics * & & 9 & & & & \\
\hline Micro Economics & & 8 & & & 2 & \\
\hline Macro Economics & & 7 & & & 2 & \\
\hline Turkish Economy & & & & & 5 & 1 \\
\hline
\end{tabular}

Table 10 shows that Introduction to Economics course is mostly included in the curriculums in compulsory basis. More than half of the programs include Micro Economics and Macro Economics mostly in compulsory basis. 
Evaluating Undergraduate Accounting Programs in Turkey According To International Accounting Education Standard (IES) 2

Table 11. Courses of 'Business Strategy and Management' Competence Area

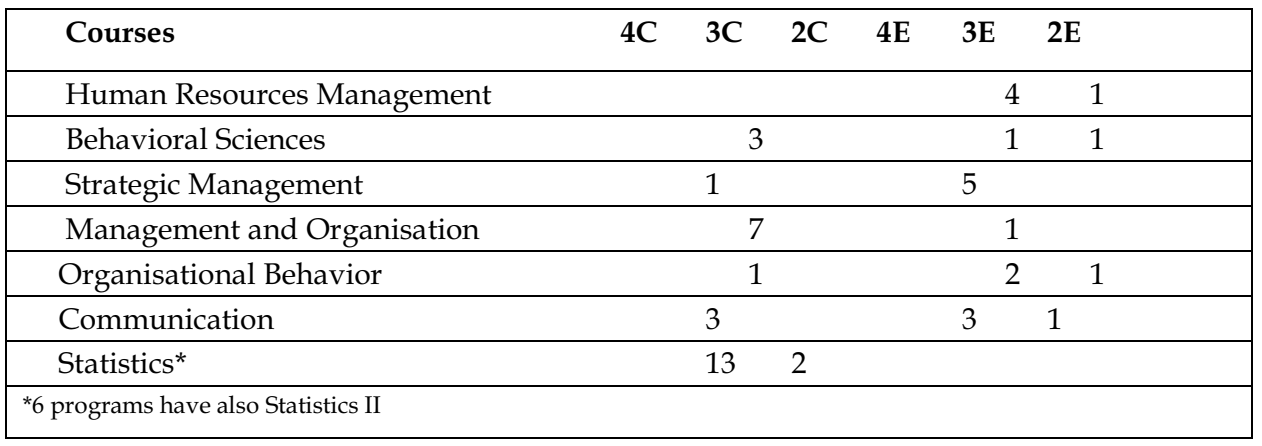

As it is seen in Table 11, the inclusion of the basic courses of Business Strategy and Management competence area in the curriculums is inadequate; only statistics course is included in all of the programs' curriculums in compulsory basis and Management and Organization course is included in more than half of the programs.

\section{CONCLUSION}

This study aims to examine accounting education of undergraduate accounting programs in Turkey with respect to International Education Standard 2 (IES 2) which is related to learning outcomes for technical competence. Curriculums of the undergraduate programs that have solely education about accounting and finance are analyzed in terms of the main courses in 11 competence areas and according to the credit hour and whether they are compulsory or elective.

Basic courses of 'Financial Accounting and Reporting', 'Management Accounting', 'Finance and Financial Management', 'Taxation', 'Audit and Assurance', 'Business Laws and Regulations' competence areas are included in all (or almost all) of the programs' curriculums. Basic courses of 'Information Technology', 'Business and Organizational Environment' and 'Economics' competence areas are included in most of the programs' curriculums. The inclusion of the basic courses of 'Governance, Risk and Internal Control' competence area and 'Business Strategy and Management' areas are less than the other areas. There were also adequate accounting and finance lessons that are necessary for the technical knowledge in Zaif and Ayanoglu (2007)'s study. In Uyar (2008)'s study, there were adequate lessons about Accounting, Finance and Organizational and business knowledge in Economics, Business Management and Public Finance programs, but information technology knowledge was inadequate. Ethics courses were inadequate in undergraduate programs in Çubukçu (2012)'s study. In this study, ethics course is included in all of the programs in elective basis. 
Prestige International Journal of Management \& IT-Sanchayan, Vol. 8 (2), 2019, pp. 1-14 ISSN : 2277-1689 (Print), 2278 - 8441 (Online)

There are various lessons with different names but similar contents in the curriculums. As Subaşı and Demir $(2009,136)$ also indicated in their study, this situation may cause problems in accordance between the universities and student exchange and there wouldn't be a harmony between the curriculums.

Sledgianowski et al. (2017) state that professional associations emphasize the importance of integrating Big Data, technology and information systems into the accounting curriculum that students be equipped with necessary skills and gain knowledge that they can adapt to the environment where the data is very important. They suggest a method in their study to facilitate that integration.

McPeak et al. $(2012,750)$ state that there may be difficulties in developing globally applicable set of international accounting education standards because of differing cultures, languages, social and legal systems, but accounting educators can also help to meet this problem by some efforts such as researching the issues addressed by the IAESB and using IAESB standards in developing and evolving accounting education programs. IESs serve the public interest by providing a consistent global framework necessary to prepare professional accountants capable of making positive contributions to the profession and society and promote consistency and convergence in the accounting education processes that are adopted throughout the world (Saville, 2007, 108). Sugahara and Watty $(2016,270)$ state that a stronger focus on increasing the perceived validity of IES among academicians and other stakeholders in accounting profession might be considered by IAESB, while continuous refinements and revisions of the standards are important for stronger credibility, reliability and validity of IES and their relevance for global accounting profession.

As Pat and Perera (2012, 105) indicate, educators should consider the market expectations for accounting graduates in designing university accounting programs, together with the educational principles. Wong and the others $(2016,64)$ state that some universities offer sustainability courses in accounting curricula; CPAs as advisors, should know to measure and report sustainability activities as more organizations give an importance to integrate sustainability into their strategies.

We suggest that there should be unity in the name and content of the courses. Educators should also cooperate with the practitioners during curriculum design. Curriculums of the accounting programs should be updated with the guidance of IESs and by the need of market; especially in Information and Communications Technology (ICT) and Professional Skepticism areas that IAESB concluded to be developed. Also ethics courses should be considered to train qualified accountants with necessary technical competence, skills, ethics and values to ensure that accountancy profession will be regarded leader in the development of strong organizations. 
Evaluating Undergraduate Accounting Programs in Turkey According To International Accounting Education Standard (IES) 2

The limitation of this study is that it analyzed the courses in respect to IES2 and according to credit hour basis and whether they are compulsory. Other studies may analyze the accounting education content detailed, not only in respect to technical knowledge but also in respect to skills and values that are also necessary for a qualified accountant.

\section{REFERENCES}

- Our Purpose Retrieved from http:/ / www.ifac.org/about-ifac (Retrieved on 08.07.2019)

- About IAESB Retrieved from https://www.iaesb.org/about-iaesb. (Retrieved on 08.07.2019)

- Exposure Draft, 2018, International Accounting Education standards BoardRetrieved from: https://www.ifac.org/system/files/publications/files/IAESBExposure-Draft-Proposed-Revisions-IES-2-3-4-8.pdf (Retrieved on 02.05.2019).

- Handbook of International Education Pronouncements, 2017, International Accounting Education standards Board-Retrieved from: https://www.ifac.org / publications-resources / 2017-handbook-international-educationpronouncements (Retrieved on 02.05.2019).

- Can, Ahmet V., and, Şuayyip D. Demirci (2016). Uluslararası Muhasebe Eğitim Standard1 2 Muhasebe Eğitim Programlarının İçeriğine Uyum: Sakarya Üniversitesi Örneği [Compability To International Education Standard 2 Content Of Professional Accounting Education Program: A Case Of Sakarya University]. Int. Journal of Management Economics and Business, ICAFR 16 Special Issue, 308-318.

- Crawford, Louise, Helliar, Christine, Monk, Elizabeth, and Monica Veneziani (2014). International Accounting Education Standards Board: Organisational legitimacy within the field of professional accountancy education. Accounting Forum, 38, 6789.

- Çubukçu, Sezen (2012). Uluslararası Muhasebe Eğitimi Standartları Komitesi Düzenlemeleri Çerçevesinde Etik Eğitimine İlişkin Durum Analizi [A Situation Analysis Related to Ethics Education in Accordance with International Accounting Education Standards Board's Regulations]. Anadolu Üniversitesi Sosyal Bilimler Dergisi, 12(1), 103-116.

- Gokten, Pınar O., and Soner Gokten (2016). Uluslararası Eğitim Standartlarına Genel Bakış: Geçerliğinin Türkiye Açısından Değerlendirilmesi [General Overview of International Accounting Standards: Evaluating the Validity with Regards to Turkey]. Gazi Üniversitesi Sosyal Bilimler Dergisi, 3(6), 49-66.

- McPeak, David, Pincus, Karen V., and Gary L. Sundem (2012). The International Accounting Education Standards Board: Influencing Global Accounting Education. Issues in Accounting Education, 27(3), 743-750.

- Nasution, Abdillah A., Wardayani, Zul A., and Iskandar Muda (2018). Influence of International Financial Reporting Standards Application on Education Accounting in Indonesia. Chinese Business Review, 17(2), 76-83.

- Öztürk, Mahmut S., and Murat Erdoğan (2017). Batı Akdeniz Bölgesinde yer alan Üniversitelerdeki Muhasebe Eğitimine Yönelik bir Araştırma [An Analysis on Accounting Educatıon of West Mediterranean Region Universities]. Mehmet Akif Ersoy Üniversitesi Sosyal Bilimler Enstitüsü Dergisi, 9(21), 162-174. 
Prestige International Journal of Management \& IT-Sanchayan, Vol. 8 (2), 2019, pp. 1-14 ISSN : 2277-1689 (Print), 2278 - 8441 (Online)

- Pat, Peipei, and Hector Perera (2012). Market relevance of university accounting programs: Evidence from Australia. Accounting Forum, 36, 91-108.

- Pippin, Sonja E, Weber, Jessica L., Wong, Jeffrey A., and Jason Bergner (2016, June). The Inclusion of Sustainability in the Accounting Curriculum. The Cpa Journal, 6467.

- Saville, Henry (2007). International Education Standards for Professional Accountants (IESs). Accounting Education: an international journal, 16(1), 107-113.

- Sledgianowski, Deb, Gomaa, Mohamed, and Christine Tan (2017). Toward integration of Big Data, technology and information systems competencies into the accounting curriculum. Journal of Accounting Education, 38, 81-93.

- Subaşı Şerife, and Berna Demir (2009). Fakültelerin İşletme Bölümlerinde Verilen Muhasebe Derslerinin Durum Analizi [Situation Analysis of Accounting Courses Given in Business Administration Departments of Faculties]. Muhasebe ve Finansman Dergisi, 44, 127-136.

- Sugahara, Satoshi, and Kim Watty (2016). Global convergence of accounting education: An exploratory study of the perceptions of accounting academics in Australia and Japan. Asian Review of Accounting, 24(3), 254-273.

- Suttipun, Muttanachai, Sattayarak, On-Anong, Duangpanya, Photjanee, and Somkao Runglertkrengkrai (2018). Relationship Between Competency As Per The International Education Standards For Accounting Professionals And The Awareness And Understanding Of The Thai Financial Reporting Standards For Small And Medium Sized Enterprises: A Case Study Of Accounting Professionals In Thailand's Southern Region. Kasetsart Journal of Social Sciences, 39, 432- 438.

- Tosunoğlu, Büşra, Cengiz, Selim, and Zafer Anadolu (2018). Uluslararası Muhasebe Eğitimi Standartları Kapsamında Muhasebe Eğitiminin Türkiye'deki Akademisyenler ve Muhasebe Meslek Mensupları Açısından İncelenmesi [Examination of Accounting Education within the scope of International Accounting Education Standards in terms of Academics and Professional Accountants in Turkey]. Optimum Journal of Economics and Management Sciences, 5(2), 179-192.

- Uyar, Süleyman (2008). Uluslararası Eğitim Standartları (IES) ve Akdeniz Üniversitesi'nde Muhasebe Eğitimi [International Education Standards and Accounting Education in Akdeniz University]. World of Accounting Science, 1, 79107.

- Zaif, Figen, and Yıldız Ayanoglu (2007). Muhasebe Eğitiminde Kalitenin Arttırılmasında Ders Programlarının Önemi: Türkiye'de Bir İnceleme [The Importance of Education Programs in Improving the Quality of Education: An Empirical Analyze in Turkey]. Gazi Üniversitesi İktisadi ve İdari Bilimler Fakültesi Dergisi, 9(1), 115-136. 